\title{
PREDICTING THE POTENTIAL BANKRUPTCY OF COAL MINING COMPANIES USING ALTMAN Z-SCORE METHOD DURING 2012-2016 PERIOD
}

Rihfenti Ernayani

Faculty of Economics, University of Balikpapan, Indonesia. Email: rihfenti@uniba-bpn.ac.id

Article History: Received on $30^{\text {th }}$ September 2019, Revised on $30^{\text {th }}$ December 2019, Published on $01^{\text {st }}$ February 2020

\section{Abstract}

Purpose of the study: This study aimed to determine and predict potential bankruptcy in coal mining companies listed in Indonesia Stock Exchange (IDX) period 2012-2016.

Methodology: This study to using the Altman Z-Score method, with five (5) ratios, namely Working Capital to Total Asset, Retained Earnings to Total Assets, Earning before interest and tax to total assets, Market Value of Equity to Book Value of Debt, and Sales to Total Assets. The ratio of working capital to total assets (X1) is a ratio of liquidity which measures the extent of working capital that is used to finance the total assets.

Main Findings: The result showed, by the Z-Score value in 2016 from the coal mining companies studied, four companies fall in the category of potential bankruptcy, three companies in the grey area, and four in the healthy category.

Applications of this study: Data sources in this study were coal mining companies listed on the Indonesia Stock Exchange (IDX) for the period 2012-2016.

Novelty/Originality of this study: There are 11 coal mining companies taken as sample based on purposive sampling. The result shows, by the Z-Score value in 2016 from the coal mining companies studied, four companies fall in the category of potential bankruptcy, three companies in the grey area, and four in the healthy category.

Keywords: Altman Z-score, Prediction, Potential Bankruptcy, Coal Mining Company, Indonesia Stock Exchange.

\section{INTRODUCTION}

In recent years, the international financial conditions of the world are relatively unstable, triggered by international issues, coupled with some of the conflicts in the Middle East that have exacerbated international world financial conditions today. From several events in the international world such as war conflicts Syria and also the conflict on the line Gazza, Palestine that was not completed, resulted in some commodity prices such as a decline and price increase - a very drastic price. With the conditions of the past few years, it has a significant impact on the current world oil prices, where Oil prices are experiencing a fairly drastic decline in the last 10 years. Oil price instability has directly impacted the decrease in the amount of revenue of mining companies In the world today, is no exception in Indonesia. The fluctuations in the world petroleum prices during 2008-2017 are seen in Figure 1 below.

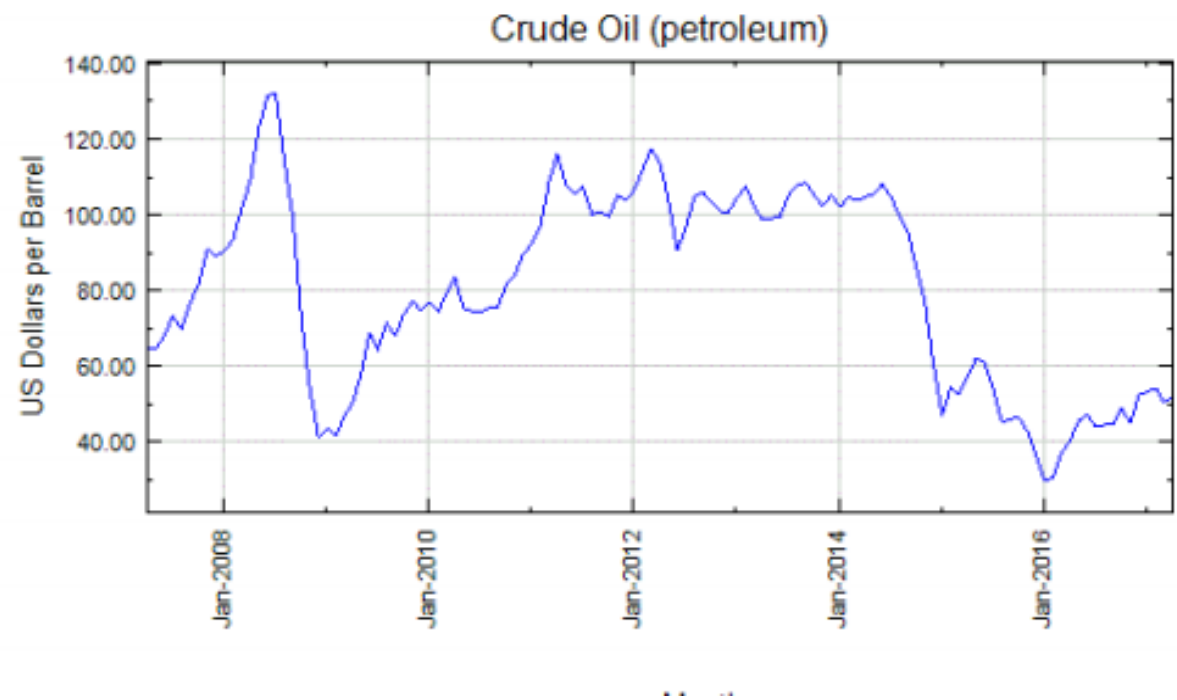

Figure 1: World petroleum prices during 2008-2017 (Mann et al., 2015)

The impact of world oil prices fluctuates at the world's declining commodity prices as well. The world coal prices of the last 10 years have decreased in line with the decline in world petroleum prices. A significant reduction in coal prices occurred in the same period as the decline in the world oil price of the period from 2012-2016. This resulted in the 
revenues of the coal mine company declining sharply and ultimately impacted the potential. The bankruptcy of such companies is not an exception to companies in Indonesia. In line with the world oil price, coal price development during the year 2008-2017 also fluctuates as seen in Figure 2 below.

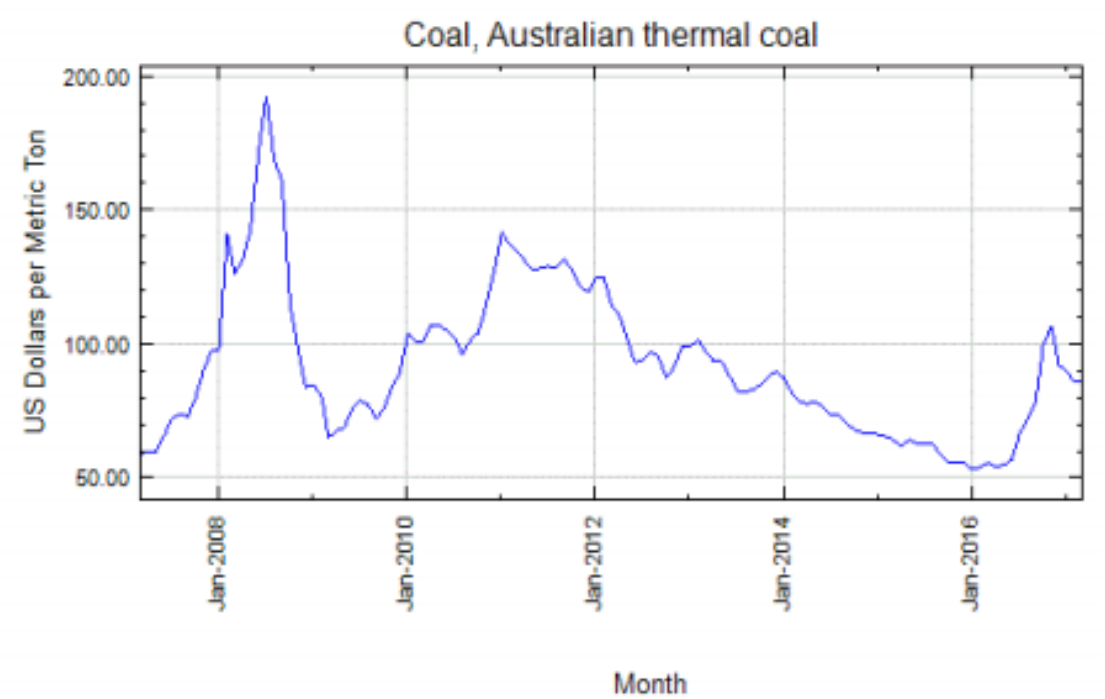

Figure 2: world petroleum prices during 2008-2017 (Pratama \& Yulianto, 2016)

The more intense corporate competition in this globalization era requires companies to perform good management so that the company has a good performance. In facing competition, every company is required to keep improving the effectiveness and efficiency of corporate management by evaluating the company's strategy and policy. The meant evaluation is to assess the performance and financial health of the company in maintaining competition, economic growth, increasing profits, investment return level, cost efficiency, and creating the economic value of the company (Triyono, 2017). The company assumes that it must continue to operate to generate profits and is expected not to be liquidated. However, in the practice of operating companies, the number of companies that have financial difficulties which ultimately lead to corporate bankruptcy is not small. If the bankruptcy condition can be detected earlier, the management of the company may perform some actions to improve the company's financial condition. It is done to minimize or even to overcome the occurrence of bankruptcy in the company. Therefore, the management must supervise the company's financial condition by analyzing the company's financial statements.

The financial statements are a means to provide financial information for stakeholders both outside and inside the company (Ernayani et al., 2017; Subramanyam \& Wild, 2010). One of the benefits of the financial statement is as a means to analyze financial ratios that aim to predict corporate bankruptcy. There are various methods developed to predict bankruptcy occurring in the company. One of which is by the use of ratio analysis of financial information presented in the company's financial reports (Ernayani \& Sari, 2017). Various analyses were developed to predict bankruptcy that becomes an early warning of corporate bankruptcy. The purpose of this early warning system is as a means to identify the circumstances as well as to improve the condition of the company before reaching crisis or even bankruptcy conditions. One of the methods that can be applied to predict the company's potential bankruptcy is the Altman method Z-Score. Altman Method Z-Score is a tool that combines several certain financial ratios of the company, in the form of a discriminant equation that will produce certain scores so that the potential companies which are going to face bankruptcy can be determined (Toto, 2011).

Some financial ratios which can be used on the Altman Z-Score method are liquidity ratio, profitability, leverage, solvency, and activity ratio (Arista, 2016). In this study, five ratios used are (1) liquidity ratios proxied with working capital ratio to total assets, (2) profitability ratio using retained earnings ratio to total assets, and (3) ratio of earnings before interests and taxes to total assets, (4) solvency ratio with ratio of market value of equity to book value of total debt, and (5) activity ratio with ratio of sales to total assets.

The ratio of working capital to total assets is a liquidity ratio that measures the extent to which existing working capital is used to finance its total assets (Van Horne \& Wachowicz, 2000). If the amount of networking capital is negative, it is likely that the company will face problems in meeting its short-term liabilities due to the high liabilities of the company as well as the insufficient current assets to meet the obligations. Conversely, companies with positive net working capital will rarely face difficulties in fulfilling their obligations (Gerald et al., 2003; Harmono, 2017). The ratio of retained earnings to total assets is the profitability ratio that measures the accumulation of the company's operation. Therefore the age of the company also influences the ratio. The lower the ratio of retained earnings to total assets means the less the role of retained earnings to total assets of the company; so that the financial distress probability of the company is higher. Meanwhile, if the role of retained earnings to total assets is greater, it indicates that retained earnings play a role in establishing corporate funds so that the financial distress probability of a company is lower. 
The ratio of earnings before interests and taxes to total assets is a measurement of the company's revenue generated from the operational activities of the company, the greater the ratio value, the higher the asset productivity level in generating revenue for the company and vice versa. The smaller the profitability level means, the more inefficient and ineffective the company uses the entire assets in generating business profits (Utama \& Sulistika, 2015). The ratio of the market value of equity to the total debt is the solvency ratio which describes the ability of a company to fulfill its liabilities, especially its long-term obligations with the book value of equity owned by the company. The ratio of sales to total assets is an activity ratio that measures management's capability to use assets to generate sales (Tong et al., 2013). This ratio is a financial ratio that is often used to measure the ability of a company's assets in generating sales. The greater the value of this ratio describes the effectiveness of management in managing corporate assets, as well as measuring the ability of management in facing conditions of corporate competition. In this research, samples were taken from coal mining companies listed on the Indonesia Stock Exchange.

Coal mining companies in Indonesia indicate a very significant development each year, as proven with 22 companies in the coal mining sector listed in Indonesia Stock Exchange in 2016. Of the 22 companies, PT. Petrosea, Tbk is the longest coal mining company listed on Indonesia Stock Exchange since May 21, 1990. While PT. Mitrabara Adiperdana, Tbk is the newest company listed on the Indonesia Stock Exchange since July 10, 2014. The coal mining industry is one of the mining sector industries which is very important for economic development in Indonesia. This is evidenced when the coal mining sector in the early 1990s was reopened for foreign investments; Indonesia experienced increased productions, exports, and domestic sales of coal. The utilization of coal in domestic is still relatively low. Indonesia's coal exports ranged from $70 \%-80 \%$ of total coal production, the rest is traded in the domestic market.

Table 1: List of Coal Production, Export, Consumption, \& Price

\begin{tabular}{|c|c|c|c|c|}
\hline \multirow[b]{2}{*}{ Years } & Production & \multirow{2}{*}{$\begin{array}{l}\text { Export (In } \\
\text { Million Ton) }\end{array}$} & Domestic & Price (HBA) \\
\hline & $\begin{array}{ll}\text { (In } & \text { Million } \\
\text { Ton) } & \\
\end{array}$ & & $\begin{array}{ll}\text { (In } & \text { Million } \\
\text { Ton) } & \\
\end{array}$ & $\begin{array}{l}\text { (In USD I } \\
\text { Ton) }\end{array}$ \\
\hline 2011 & 353 & 287 & 66 & 118.4 \\
\hline 2012 & 412 & 345 & 67 & 95.5 \\
\hline 2013 & 474 & 402 & 72 & 82.9 \\
\hline 2014 & 458 & 382 & 76 & 72.6 \\
\hline 2015 & 461 & 366 & 87 & 60.1 \\
\hline 2016 & 419 & 333 & 86 & 61.8 \\
\hline
\end{tabular}

Source: Indonesian Coal Mining Association (APBI) and Ministry of Energy and Mineral Resources

Based on data in Table 1, coal production has shown increasing production, due to the high demand for exporting coal to China, India, Japan, and Korea. As for the coal consumption level in Indonesia is still very low. However, the price of coal is fluctuated and tends to decline at the end of the period. This may affect the company's financial condition, especially for companies that have made a public offering or go public. One factor affecting the decline in coal prices is the decline in global economic activity thereby decreasing coal demand and causing low coal prices. The low coal price is a major problem that causes business performance in this sector to decrease and even declines very significantly. Many coal mining companies, both small and large, experienced bankruptcy and huge losses due to the decreasing coal prices, even there are companies that eventually went bankrupt.

A research conducted by $\operatorname{Arista}(2016)$ discusses the potential bankruptcy of going to public retail companies. The research result concluded that of the five sample companies, three companies were declared financially healthy, one company was prone to bankruptcy, and one company was predicted to be bankrupt. A company is healthy because it can improve its financial performance. Onyskow(2014) discusses the analysis of financial ratios to predict the bankruptcy of coal mining companies in 2011-2012. Based on the Altman Z-score model calculation value which has been calculated, it was predicted that in 2012 there were three companies in the potential bankrupt category, 2 in grey area category, and eight companies were in the financially healthy category. Irfan(2014) examines the potential bankruptcy of telecommunication companies. The results showed that the financial condition of the telecommunication companies being sampled was in the financial distress category. Variable of net working capital to total assets and EBIT to total assets provides an effect on financial distress level in telecommunication companies. Marcelina \& Yuliandari(2014) studied transportation companies. The results showed that the bankruptcy prediction using the Altman Z Score method does not affect the stock price of transportation companies.

Based on the descriptions, the purpose of this research is to identify and to predict the potential bankruptcy on coal mining companies listed in Indonesia Stock Exchange (IDX) for the 2012-2016 period using the Altman method ZScore. 


\section{LITERATURE REVIEW}

\section{Financial statements}

According to Penman(2007) in general, the financial statements consist of balance sheet and income statement calculation as well as report changes in equity. The balance sheet shows or describes the number of assets, liabilities, and equity of a company on a given date. While the calculations (reports) Income statement show results that have been achieved by the company, as well as the burden incurred during a certain period and the report on equity changes, shows the source and use or reasons that cause Changes in company equity (Cao et al., 2015).

Following the Statement of Financial Accounting Concepts No. 1 on the purpose of Financial reporting to provide useful information to investors, creditors and other users, both as well as the potential for decision making Investments, credits and similar decisions. The second objective of financial reporting To provide information to help investors, creditors, and other users both present and potential in the value of the amount, time and uncertainty of prospective cash receipts from dividends or interest (Scott, 2000).

\section{BANKRUPTCY}

Failures of the bank are the bank Failed attempts or bank problems (Meyer \& Pifer, 1970), financial distress (Platt \& Platt, 2002). The failing bank has one or both of the two The following criteria: First, the bank requires financial support and or Management support from the Government in conducting its operations. Second Based on the level of health of the bank, including into the bank Less healthy and unhealthy (Suharman, 2007). Liou (2007) uses the term financial distress to demonstrate the Unbreakable liquidity issues without scaling Of the company's operations or structures. Financial distress is the best view as an idea/idea/economic mind to Multiple points on a set of unity. Empirical research on this area Objective criteria to categorize the company. Bankruptcy is a criterion used in many studies; Event in I is a Legal event that can be influenced by action bankers or other creditors.

Although the alleged financial distress is binary, it is not necessary to be a One agrees between a nondistressed/distressed category and a category nonbankrupt/bankrupt:

According to (Almeida \& Philippon, 2007; Altman, 2013; Elloumi \& Gueyie, 2001) Bankruptcy (financial distress) is essentially difficult to define right. This is due to various occurrences of the company's downfall during financial distress. The downfall event of a financial caused company distress almost no end, such as the following: the occurrence of dividend deduction, company closure, losses, dismissal, the resignation of directors and the fall of the stock price.

Research on financial ratios of the banking used to indicate bankruptcy has been conducted in 1977 by Altman, Holdeman, and Narayan. They formulate a model called Zeta analysis which is a model used to recognize the risk of bankruptcy of the company( Altman et al., 1977).

The ratios used in these models are Return on Asset, Stability of Earnings, Debt Service, Cumulative Profitability, Liquidity, Capitalization, and Size. The model was used to test the bankruptcy banks and banks that remained in developed countries in the year 1982, which is the period 0.5 years up to 3.5 years before the fall with a level of accuracy of $73 \%$ to $80 \%$ (Sukristono, 1992).

In early 1999, Banks (2004) used the technique A different test analysis of one aspect of The CAMEL's Earning (ROA and efficiency) ratio of categories A, B and C Banks is limited to national private banks that have assets of 250-500 billion rupiahs. The results mentioned that there were no significant differences between the three banks category group Due diligence results from Assets of 250 - 500 billion.

Previous research results about predicting bankruptcy of coal mining companies are : (Boulila et al., n.d.; Sun, 2007; Syamni, Majid, \& Siregar, 2018). Based on previous research, the novelty of this research is that the bankruptcy of coal mining companies can be predicted early by using the Altman Z-score method.

\section{METHOD}

The population of this study was all coal mining companies that have been going public in Indonesia Stock Exchange during 2012-2016 period in which 22 companies were listed. The samples were selected using purposive sampling method based on specific criteria, namely (1) the coal mining companies which publish the financial statements and annual reports of 2012-2016 completely, (2) the financial statements have been audited, and (3) the financial statements are presented in US dollars. This research used secondary data in the form of financial statements that have been audited that are sourced from the Indonesia Capital Market Directory (ICMD). Based on the criteria obtained samples selected were 11 companies as follows:

Table 2: List of the Sample Companies

\begin{tabular}{lll}
\hline NO & TICKER CODE & NAME OF ISSUERS \\
\hline 1 & ADRO & PT Adaro Energy Tbk \\
\hline 2 & ARII & PT Atlas Resources Tbk \\
\hline
\end{tabular}




\begin{tabular}{lll}
\hline 3 & BSSR & PT Baramulti Suksessarana Tbk \\
\hline 4 & BYAN & PT Bayan Resources Tbk \\
\hline 5 & DEWA & PT Darma Henwa, Tbk \\
\hline 6 & DOID & PT Delta Dunia MakmurTbk \\
\hline 7 & HRUM & PT Harum Energy Tbk \\
\hline 8 & ITMG & PT Indo Tambangreya MegahTbk \\
\hline 9 & PTRO & PT PetroseaTbk \\
\hline 10 & KKGI & PT Resource Alam Indonesia Tbk \\
\hline 11 & TOBA & PT Toba Bara SejahteraTbk \\
\hline
\end{tabular}

This study used the Altman Z-Score method with five (5) ratios, namely Working Capital to Total Asset, Retained Earnings to Total Assets, Earning before interest and tax to total assets, Market Value of Equity to Book Value of Debt, and Sales to Total Assets. The ratio of working capital to total assets (X1) is a ratio of liquidity which measures the extent of working capital that is used to finance the total assets. This ratio measures the company's capability of fulfilling short-term liabilities. The indicators to detect the occurrence of a problem on the company's liquidity include inadequacy of cash and highly increased debt, and some other indicators. The magnitude of this ratio is obtained by dividing the net working capital with the total asset. The net working capital is the difference between the current assets with the current liabilities.

$$
\mathrm{X} 1=\quad \frac{\text { Current Assets }- \text { Current liabilities }}{\text { Total Assets }}
$$

The ratio of retained earnings of the total assets (X2) is a ratio of profitability which shows the company's ability in producing the retained earnings from the total assets that are owned by the company. The retained earnings occur because the stockholders usually permit to reinvest the profit that is not shared with them. The lower the value of the retained earnings ratio to the total assets, the company's probability to experience the financial distress condition can be higher. In contrast, the higher the retained earnings of the total assets show that the company's probability to experience the condition of the financial distress is smaller. This ratio is calculated by dividing the retained earnings with the total assets of the company.

$$
\mathrm{X} 2=\quad \frac{\text { Retained Earnings }}{\text { Total Assets }}
$$

The ratio of earnings before interests and taxes to the total asset (X3) measures the company's capability to generate income that is by dividing the annual earnings before interests and taxes with the total assets. The greater the value of the ratio, the level of assets productivity in generating profit for the company will increase and vice versa. The indicators to detect the existence of problems in profitability include the decline of sales, the delay of account receivable collection output, and the increasing account receivable.

$$
\mathrm{X} 3=\frac{\text { Earnings before interests and taxes }}{\text { Total Assets }}
$$

The ratio of the market value of equity to the total debt (X4) is a ratio of solvency. This ratio measures the capability of corporate capital entrusted with the overall debt, especially the long-term liabilities with the book value of equity owned by the company. The market value of equity is obtained by multiplying the number of shares circulates with the market price per stock. The book value of debt is obtained by summing up the current liabilities with long-term liabilities. The smaller the ratio shows the unhealthy condition of the company's financials.

$$
\mathrm{X} 4=\frac{\text { Number of Shares Circulate } \mathrm{x} \text { Stock Price }}{\text { Total of Liabilities }}
$$

The sales ratio to the total assets (X5) is a ratio of activities that measures the management's capability in using the assets to generate sales. The greater value of this ratio describes the effectiveness of management in managing the company's assets, also measures the management's capability in facing competitive conditions. Analysis of the company's financial condition is done as a means to excavate the relationship of significant information to the purpose, profitability, efficiency, and level of the company's risk.

$$
\mathrm{X} 5=\frac{\text { Sales }}{\text { Total Asset }}
$$


The technique of data analysis done firstly was by examining the financial statements of coal mining companies. Secondly, analyzing the descriptive statistics to figure out the average, minimum, maximum, and standard deviation values in 11 coal mining companies used as a sample of this research based on the results data from the financial ratio of the Altman Z-Score method. Thirdly, calculating the value of Z-Score in 2012-2016 period by inputting the value of ratios that have been calculated into the equation of Altman Z-Score method as follows:

$$
\mathrm{Z}=1.2 \mathrm{X} 1+1.4 \mathrm{X} 2+3.3 \mathrm{X} 3+0.6 \mathrm{X} 4+1.0 \mathrm{X} 5
$$

Fourthly, clarifying the corporate financial performance based on the criteria of Z-Score value yielded by cut-off that has been specified in the Altman Z-Score method, they are:

a. If Z-Score <1.81, the company is in the category of potential bankruptcy and is experiencing bankruptcy or financial distress.

b. If $1.81>$ Z-Score $<2.99$, the company is in the category of a grey area, the company has financial distress, but there is a possibility to be saved from the potential bankruptcy and the possibility of bankruptcy with the same magnitude.

c. If $2.99<\mathrm{Z}$-Score, the company is in the category of healthy or is not experiencing financial distress and does not have the potential to experience bankruptcy.

\section{RESULT}

\section{The Results of Descriptive Statistical Analysis}

Descriptive statistic analysis is used to determine the values of average, minimum, maximum, and standard deviation of variables. The results of the descriptive statistics of X1, X2, X3, X4, and X5 from 2012 to 2016 in the coal mining companies are as follows:

Table 3: The Results of Descriptive Statistical Analysis

\begin{tabular}{llllll}
\hline Variable & $\mathbf{N}$ & Minimum & Maximum & Mean & Std. deviation \\
\hline $\mathrm{X} 1$ & 55 & -0.51 & 0.52 & 0.09 & 0.22 \\
\hline $\mathrm{X} 2$ & 55 & -0.28 & 1.04 & 0.18 & 0.31 \\
\hline $\mathrm{X} 3$ & 55 & -0.17 & 0.40 & 0.07 & 0.12 \\
\hline $\mathrm{X} 4$ & 55 & 0.05 & 15.20 & 2.75 & 3.15 \\
\hline $\mathrm{X} 5$ & 55 & 0.04 & 2.07 & 0.90 & 0.49 \\
\hline
\end{tabular}

Source: Processed Data

The results of descriptive statistic analysis in Table 3 show that $\mathrm{X} 1$ is a ratio of liquidity which is obtained by dividing the working capital with the total assets, which has a maximum value of 0.52 and a minimum value of -0.51 and the average value of 0.09 . The variable of $\mathrm{X} 2$ which is a ratio of profitability is obtained by dividing the retained earnings with the total asset has a maximum value of 1.04 , and a minimum value of -0.28 and the average value of X2 is 0.18 . The variable of $\mathrm{X} 3$ is a ratio of profitability which is obtained by dividing the earnings before interest and tax with the total asset, which has a maximum value of 0.40 and minimum value of -0.17 and the average value of $\mathrm{X} 3$ is 0.07 . The variable of X4 which is a ratio of activities that is obtained by dividing the market value of equity with a book value of debt has a maximum value of 15.20 and a minimum value of 0.05 and the average value of $\mathrm{X} 4$ is 2.75 . The variable of $\mathrm{X} 5$ which is a ratio of activities is obtained by dividing the sales to the total assets has a maximum value of 2.07 and a minimum value of 0.04 and the average value of X5 is 0.90 . Viewed from the average value of the coal mining companies from 2012 to 2016 which have the highest average value is found in the variable of X4 of 2.75 compared with the other variables.

Based on Table 3, the values of variables X1, X2, X3, and X5 have a low average value. Variable X1 has 0.09 of value which means that all the coal mining companies are unable to guarantee the working capital required. Coal mining companies commonly have a low value of X1 because the companies have greater current liabilities than the current assets. Variable X2 shows 0.18 of value which means the coal mining companies are incapable of generating the retained earnings as expected. Variable X3 yields a value of 0.07 which means the productive assets of coal mining companies are incapable yet to generate the corporate profits as planned. X4 is the highest variable with an average value of 2.75 which means the coal mining companies have a high market value of equity than the amount of debt. Variable X5 has a value of 0.90 which means the coal mining companies have not been able to perform sales to achieve the expected target.

\section{The Result of the Altman Z-Score Method}

Analysis of Altman Z-Score method is used to observe the financial distress condition of coal mining companies studied with the calculation of each ratio of $\mathrm{X} 1, \mathrm{X} 2, \mathrm{X} 3, \mathrm{X} 4$, and $\mathrm{X} 5$ that are included in the following equation:

$$
\mathrm{Z}=1,2 \mathrm{X} 1+1,4 \mathrm{X} 2+3,3 \mathrm{X} 3+0,6 \mathrm{X} 4+1,0 \mathrm{X} 5
$$


Afterward, the score or result of the equation is analyzed with a certain cut-off score of the Altman Z method. The result of the analysis of the Altman Z-Score method on coal mining during 2012-2016 is illustrated in the following Table 4 .

Table 4: The Result of Altman Z-Score in $2012-2016$

\begin{tabular}{lllllll}
\hline \multirow{2}{*}{ No } & \multirow{2}{*}{ Ticker code } & Year & & & & \\
\cline { 3 - 7 } & & $\mathbf{2 0 1 2}$ & $\mathbf{2 0 1 3}$ & $\mathbf{2 0 1 4}$ & $\mathbf{2 0 1 5}$ & $\mathbf{2 0 1 6}$ \\
\hline 1 & ADRO & 2.07 & 1.51 & 1.59 & 1.36 & 2.13 \\
\hline 2 & ARII & 3.23 & 1.30 & 0.60 & -0.74 & -0.93 \\
\hline 3 & BSSR & 7.12 & 4.25 & 4.11 & 4.37 & 5.53 \\
\hline 4 & BYAN & 3.58 & 1.85 & 1.05 & 1.80 & 2.27 \\
\hline 5 & DEWA & 0.76 & 0.12 & 0.90 & 0.76 & 0.73 \\
\hline 6 & DOID & 0.86 & 0.61 & 0.98 & 0.83 & 1.21 \\
\hline 7 & HRUM & 13.42 & 7.28 & 4.90 & 3.88 & 10.23 \\
\hline 8 & ITMG & 9.24 & 6.74 & 5.00 & 3.38 & 5.57 \\
\hline 9 & PTRO & 1.86 & 1.67 & 1.72 & 1.09 & 1.34 \\
\hline 10 & KKGI & 9.56 & 6.95 & 4.14 & 3.94 & 9.01 \\
\hline 11 & TOBA & 2.67 & 2.30 & 3.06 & 2.48 & 2.55 \\
\hline
\end{tabular}

Source: Processed data

Based on Table 4. the result of the Z-score from 2012 to 2016 shows that most of the coal mining companies experienced declining financial conditions from 2013 to 2015. PT Baramulti Suksessarana Tbk, PT Harum Energy Tbk, PT Indo Tambangreya Megah Tbk, and PT Resource Alam Indonesia Tbk underwent a significant decrease from 2013 to 2015 and experienced a significant increase in 2016. Nevertheless, those companies are still in a healthy category and show no financial difficulties.

PT Adaro Energy Tbk, PT Bayan Resources Tbk, and PT Toba Bara Sejahtera Tbk experienced decreases from 2013 to 2015 and a slight increase in 2016. However, those companies are in the grey category which means that they face financial difficulties but are safe from potential bankruptcy. PT Atlas Resource Tbk, PT Darma Henwa Tbk, PT Delta Dunia Makmur Tbk, and PT Petrosea Tbk have a very significant decrease from 2012 to 2015 and have increased slightly on PT Delta Dunia Makmur Tbk and PT Petrosea Tbk. However, both of them are in financial distress or have potential bankruptcy. It may give a negative effect on the condition of the company. Therefore, the management should evaluate and take action to restore the company position in a healthy category.

The classification result of potential bankruptcy condition or financial distress of a coal mining company in 2012-2016 shown in Table 5. Table 5 shows the prediction of the financial distress of the coal mining company in 2012. There were two companies in the potential bankruptcy category and facing financial distress. Then, three companies were in the grey area, and six companies are in a healthy condition. In 2013, there were five companies in the potential bankruptcy category and facing financial distress. Two companies were in the grey area, and four companies were in healthy categories. In 2014, there were six companies in the potential bankruptcy category and facing financial distress. There were no companies in the grey area and five companies in a healthy category. In 2015, there were six companies in the potential bankruptcy category and facing financial distress. One company was in the grey area, and four companies were in the healthy category. In 2016 there were four companies in the potential bankruptcy category and facing financial distress. There were three companies in the grey category, and four companies were in the healthy category.

Table 5: The Classification Result of Potential Bankruptcy during 2012 - 2016

\begin{tabular}{|c|c|c|c|c|c|c|}
\hline \multirow{2}{*}{ No } & \multirow{2}{*}{$\begin{array}{l}\text { Ticker } \\
\text { Code }\end{array}$} & \multicolumn{5}{|l|}{ Year } \\
\hline & & 2012 & 2013 & 2014 & 2015 & 2016 \\
\hline 1 & ADRO & Grey Area & $\begin{array}{l}\text { Potential } \\
\text { Bankruptcy }\end{array}$ & $\begin{array}{l}\text { Potential } \\
\text { Bankruptcy }\end{array}$ & $\begin{array}{l}\text { Potential } \\
\text { Bankruptcy }\end{array}$ & Grey Area \\
\hline 2 & ARII & Healthy & $\begin{array}{l}\text { Potential } \\
\text { Bankruptcy }\end{array}$ & $\begin{array}{l}\text { Potential } \\
\text { Bankruptcy }\end{array}$ & $\begin{array}{l}\text { Potential } \\
\text { Bankruptcy }\end{array}$ & $\begin{array}{l}\text { Potential } \\
\text { Bankruptcy }\end{array}$ \\
\hline 3 & BSSR & Healthy & Healthy & Healthy & Healthy & Healthy \\
\hline 4 & BYAN & Healthy & Grey Area & $\begin{array}{l}\text { Potential } \\
\text { Bankruptcy }\end{array}$ & $\begin{array}{l}\text { Potential } \\
\text { Bankruptcy }\end{array}$ & Grey Area \\
\hline 5 & DEWA & $\begin{array}{l}\text { Potential } \\
\text { Bankruptcy }\end{array}$ & $\begin{array}{l}\text { Potential } \\
\text { Bankruptcy }\end{array}$ & $\begin{array}{l}\text { Potential } \\
\text { Bankruptcy }\end{array}$ & $\begin{array}{l}\text { Potential } \\
\text { Bankruptcy }\end{array}$ & $\begin{array}{l}\text { Potential } \\
\text { Bankruptcy }\end{array}$ \\
\hline 6 & DOID & $\begin{array}{l}\text { Potential } \\
\text { Bankruptcy }\end{array}$ & $\begin{array}{l}\text { Potential } \\
\text { Bankruptcy }\end{array}$ & $\begin{array}{l}\text { Potential } \\
\text { Bankruptcy }\end{array}$ & $\begin{array}{l}\text { Potential } \\
\text { Bankruptcy }\end{array}$ & $\begin{array}{l}\text { Potential } \\
\text { Bankruptcy }\end{array}$ \\
\hline 7 & HRUM & Healthy & Healthy & Healthy & Healthy & Healthy \\
\hline 8 & ITMG & Healthy & Healthy & Healthy & Healthy & Healthy \\
\hline 9 & PTRO & Grey Area & Potential & Potential & Potential & Potential \\
\hline
\end{tabular}




\begin{tabular}{lllllll}
\hline & & & Bankruptcy & Bankruptcy & Bankruptcy & Bankruptcy \\
\hline 10 & KKGI & Healthy & Healthy & Healthy & Healthy & Healthy \\
\hline 11 & TOBA & Grey Area & Grey Area & Healthy & Grey Area & Grey Area \\
\hline
\end{tabular}

Source: Processed data

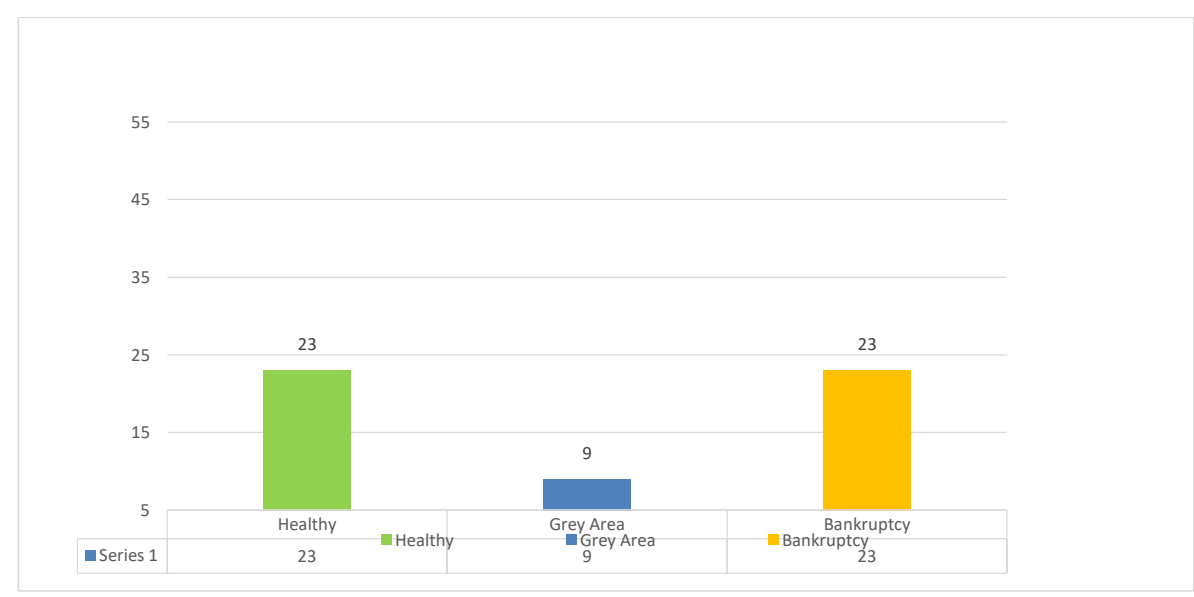

Figure 3: The calculation result Altman z-score period 2012-2016

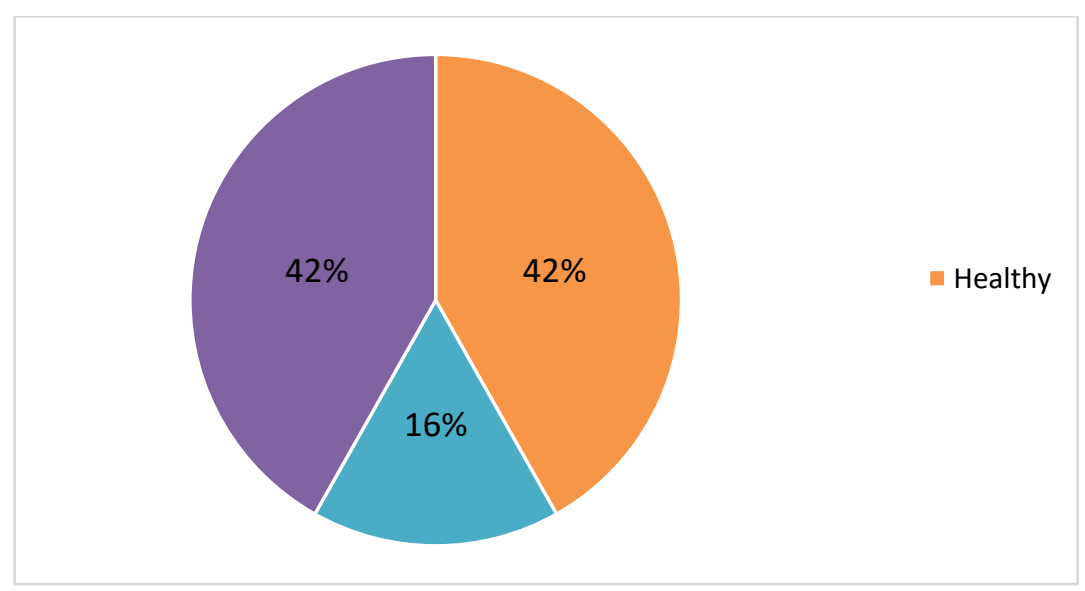

Figure 4: The percentage result Altman z-score period 2012-2016

Table 5, figure 3, and figure 4 show that from 55 (fifty-five) observations data of coal mining companies for the period 2012-2016, there are 23 (twenty-three) financial data of the company or by $42 \%$ (forty-two percent) in the criteria (Z>2.99), 9 (nine) financial data of the company or $16 \%$ (sixteen percent) in the gray area criteria and 23 (twenty-three) financial data of the company or by $42 \%$ (forty-two percent) in potential condition of bankruptcy.

Companies classified into a grey area and potential bankruptcy based on Z-score tend to be low and negative; it is because the financial performance of the companies in generating revenue is smaller compared to cost product that is increasing from year to year. Based on Z-score, the cause of the decline in financial performance is the working capital to total assets (X1) due to the unavailability of sufficient current corporate assets to meet the short-term liabilities. The total amount of liabilities is consistently increasing from year to year that causes ineffectiveness in the use of total corporate assets. This condition will lead the company to face increasing financial difficulties. Retained earnings to the total assets (X2), the low retained earnings to total assets may lead to the smaller proportion of the retained earnings as well as the retained earnings can be used to expand the business, pay liabilities, and finance the corporate operations.

The low retained earnings will lead the company to experience higher financial difficulties. Earnings before interest and tax to the total asset (X3), due to the company's inefficiency and ineffectiveness in utilizing the total assets owned for business operations because of the smaller value reflects, the lower capability of corporate to generate earnings before interest and tax to total assets. Market Value of Equity to Book Value of Debt (X4), with the combination of the capitals, companies can fulfill the short term and long term liabilities with the book value of equity owned. However, if the combined capital has a smaller value than the total liabilities, it may lead the company to encounter financial difficulties or higher potential bankruptcy. Sales to Total Asset (X5), a company may perform sales production by utilizing the total 
assets of the company. The higher value of sales represents the effectiveness of management in managing the corporate assets, besides also as a measure of the management capability in dealing with competitive conditions.

\section{CONCLUSION}

Based on the data analysis results of financial statements in coal mining companies listed in Indonesia Stock Exchange from 2012 to 2016 by using Altman Z-Score method, the conclusions can be drawn as follows:

a. The result of the calculation of variable X1 working capital to the total asset in each coal mining company tends to be negative. This is due to the negative company's working capital. The negative working capital can face problems in fulfilling the short-term liabilities. It is caused by the number of the company's liabilities has increased while the current assets available are not sufficient to meet those obligations.

b. The result of the calculation of variable X2 retained earnings to total assets; there are 4 (four) companies with the negative result that are PT Atlas Resources Tbk, PT Bayan Resources Tbk, PT Darma Henwa Tbk, and PT Delta Dunia Makmur Tbk. This is due to the negative retained earnings, so the possibility for the company to experience financial distress is getting higher since the retained earnings play an essential role in the opportunities of the company's growth in the future.

c. The result of calculation for variable X3, earnings before interests and taxes to total assets, there are 6 (six) companies which are experiencing negative value, but only PT Atlas Resources Tbk which is experiencing the negative condition in 4 (four) consecutive years. This is due to the earnings before interests and taxes are negative. The smaller the profitability level means, the more inefficient and ineffective the companies use the total assets to generate corporate income.

d. The result of the calculation for variable $\mathrm{X} 4$, market value of equity to book value of debt in each company, is positive. It reflects that the companies can fulfill the long-term liabilities from the equity owned.

e. The result of the calculation of variable X5, sales to total assets in each company, is positive. It suggests that the companies are still capable of performing sales or revenue by utilizing the available assets.

f. From the calculations of X1, X2, X3, X4, and X5 ratios in the coal mining companies during of 2012-2016 show that $\mathrm{X} 1, \mathrm{X} 2$, and $\mathrm{X} 3$ are ratios that are most influential in predicting the potential bankruptcy or financial distress of the coal mining companies since some of the companies studied have negative value in those ratios.

g. In general, the coal mining companies show unhealthy financial conditions from 2012-2016 and potentially experience financial distress and even bankruptcy. This is indicated by the value of Z-Score in 2016 from the coal mining companies studied which show that there are 4 (four) companies are in the potential bankruptcy category, 3 (three) are in the category of a grey area, and 4 (four) companies are in the category of healthy.

\section{LIMITATION AND FORWARD STUDY}

Although this study has contributed significantly to the lack of literature on Indonesian coal mining bankruptcy, there are some limitations. This study focuses only on fundamental internal variables. Therefore, further research must elaborate on both internal and external variables.

\section{IMPLICATION}

Although this study has contributed significantly to the lack of literature on Indonesian coal mining bankruptcy, this study can be beneficial for stakeholders. Further research must elaborate on both internal and external variables. This research will contribute to the knowledge of the economic concept.

\section{ACKNOWLEDGMENT}

We would like to show our gratitude to the Faculty of Economics, University of Balikpapan, Indonesia, and to the independent reviewers of HSSR who conducted a feasibility study of our research work

\section{REFERENCES}

1. Almeida, H., \& Philippon, T. (2007). The risk-adjusted cost of financial distress. The Journal of Finance, 62(6), 2557-2586. https://doi.org/10.1111/j.1540-6261.2007.01286.x

2. Altman, E I, Brenner, M., \& Eisenbeis, R. A. (1977). Zeta Analysys A New Model to Identify Bankruptcy Risk of Corporations. Journal of Banking and Finance, June, 29-54. https://doi.org/10.1016/0378-4266(77)90017-6

3. Altman, Edward I. (2013). Predicting financial distress of companies: revisiting the Z-score and ZETA® models. In Handbook of research methods and applications in empirical finance. Edward Elgar Publishing. https://doi.org/10.4337/9780857936097.00027

4. Arista, T. W. (2016). Analisis diskriminan altman z-score untuk memprediksi kebangkrutan pada perusahaan ritel go public.

5. Banks, J. M. (2004). The technology of low-fat cheese manufacture. International Journal of Dairy Technology, 57(4), 199-207. https://doi.org/10.1111/j.1471-0307.2004.00136.x 
6. Boulila, H., Benbouziane, M., Sakanko, M. A., David, J., Djulius, H., Ahmed, F., Awais, I., Kashif, M., Syamni, G., \& Majid, M. S. A. (n.d.). Determinants of Inflation in the Local Economy Jaka Sriyana Austerity in Time of Crisis: a Solution or a Dangerous Idea? Evidence from Algeria.

7. Cao, Y., Myers, J. N., Myers, L. A., \& Omer, T. C. (2015). Company reputation and the cost of equity capital. Review of Accounting Studies, 20(1), 42-81. https://doi.org/10.1007/s11142-014-9292-9

8. Elloumi, F., \& Gueyie, J.-P. (2001). Financial distress and corporate governance: an empirical analysis. Corporate Governance: The International Journal of Business in Society, 1(1), 15-23. https://doi.org/10.1108/14720700110389548

9. Ernayani, R., Robiyanto, R., \& Sudjinan, S. (2017). Factors influencing profit distribution management of sharia commercial banks in Indonesia. Journal of Economics, Business \& Accountancy Ventura, 20(2), 187192. https://doi.org/10.14414/jebav.v20i2.1055

10. Ernayani, R., \& Sari, O. (2017). The effect of return on investment, cash ratio, and debt to total assets towards dividend payout ratio (a study towards manufacturing companies listed in Indonesia stock exchange). Advanced Science Letters, 23(8), 7196-7199. https://doi.org/10.1166/asl.2017.9328

11. Gerald, I., White, S., Ashwinpaul, C., \& Fried, D. (2003). AIMR Annual Report Supplement to Accompany The Analysis and Use of Financial Statements. John Wiley \& Sons.

12. Harmono, H. (2017). Relationship between macroeconomic fundamentals, bank's credit scheme, firm's performance and firm's value dimensions. Jurnal Keuangan Dan Perbankan, 21(1), 82-95. https://doi.org/10.26905/jkdp.v21i1.1229

13. Irfan, M., \& Yuniati, T. (2014). Analisis Financial Distress dengan Pendekatan Altman Z-Score untuk Memprediksi Kebangkrutan Perusahaan Telekomunikasi. Jurnal Ilmu \& Riset Manajemen, 3(1), 1-18

14. Liou, D. K. (2007). Macroeconomic Variables and Financial Distress. Journal of Accounting, Business \& Management, 14.

15. Mann, P., Sun, L., \& Sternbach, C. (2015). Emerging Trends From 114 Giant Oil and Gas Fields Discovered From the Decade 2008-2017. AAPG Hedberg Conference, The Evolution of Petroleum Systems Analysis.

16. Marcelina, T. A., \& Yuliandari, W. S. (2014). Prediksi Kebangkrutan Menggunakan Metode Z-Score Dan Pengaruhnya Terhadap Harga Saham Pada Perusahaan Transportasi Yang Terdaftar Di Bursa Efek Indonesia Tahun 2008-2012. EProceedings of Management, 1(3).

17. Meyer, P. A., \& Pifer, H. W. (1970). Prediction of bank failures. The Journal of Finance, 25(4), 853-868. https://doi.org/10.1111/j.1540-6261.1970.tb00558.x

18. Onyskow, G. A. (2014). Analisis rasio keuangan untuk memprediksi kebangkrutan perusahaan (Survei Pada Perusahaan Tambang Batubara yang Terdaftar di Bursa Efek Indonesia Tahun 2011-2012). Universitas Widyatama.

19. Penman, S. H. (2007). Financial reporting quality: is fair value a plus or a minus? Accounting and Business Research, 37(sup1), 33-44. https://doi.org/10.1080/00014788.2007.9730083

20. Platt, H. D., \& Platt, M. B. (2002). Predicting corporate financial distress: reflections on choice-based sample bias. Journal of Economics and Finance, 26(2), 184-199. https://doi.org/10.1007/BF02755985

21. Pratama, D., \& Yulianto, E. (2016). Analisis Nilai Tukar Rupiah, Produksi Batubara, Permintaan Batubara Dalam Negeri Dan Harga Batubara Acuan Terhadap Volume Ekspor Batubara Indonesia (Studi\|l pada Ekspor Batubara Indonesia Tahun| 2005-2014). Jurnal Administrasi Bisnis, 33(2), 145-153.

22. Scott, W. R. (2000). Financial Accounting Theory. Canada: Prentice Hall.

23. Subramanyam, K. R., \& Wild, J. J. (2010). Analisis Laporan Keuangan (financial statement analysis). Jakarta: Salemba Empat.

24. Suharman, H. (2007). Analisis Risiko Keuangan untuk Memprediksi Tingkat Kegagalan Usaha Bank. Jurnal Imiah ASET, 9(1).

25. Sukristono. (1992). Perencanaan strategis bank. Lembaga Pengembangan Perbankan Indonesia.

26. Sun, L. (2007). A re-evaluation of auditors' opinions versus statistical models in bankruptcy prediction. Review of Quantitative Finance and Accounting, 28(1), 55-78. https://doi.org/10.1007/s11156-006-0003-x

27. Syamni, G., Majid, M. S. A., \& Siregar, W. V. (2018). Bankruptcy Prediction Models and Stock Prices of the Coal Mining Industry in Indonesia. Etikonomi: Jurnal Ekonomi, 17(1). https://doi.org/10.15408/etk.v17i1.6559

28. Tong, S., Junarsin, E., \& Davidson, W. (2013). A comparison of Chinese state-owned enterprise firm's boards and private firm's boards. Proceedings of 23rd International Business Research Conference 18-20 November, 2013 Melbourne, Australia. Retrieved From.

29. Toto, P. (2011). Analisis laporan keuangan teori dan aplikasi. Jakarta: PP.

30. Triyono, D. (2017). The effect of foreign stock indexes and Indonesia's macroeconomics variables toward Jakarta Composite Stock Price Index (JCI). Advanced Science Letters, 23(8), 7211-7214. https://doi.org/10.1166/asl.2017.9332

31. Utama, C. A., \& Sulistika, M. (2015). Determinants of investment opportunity set (degree of internationalization and macroeconomic variables). Gadjah Mada International Journal of Business, 17(2), 107. https://doi.org/10.22146/gamaijb.6905

32. Van Horne, J. C., \& Wachowicz, J. M. (2000). Fundamentals of financial management. FINANCE INDIA, $14(2), 621-622$. 